Audiology

Neurotology
Audiol Neurotol 2016;21:187-194

DOI: $10.1159 / 000444120$
Received: October 29, 2015 Accepted: January 15, 2016 Published online: June 1, 2016

\title{
Paediatric Cochlear Implantation in Patients with Waardenburg Syndrome
}

\author{
Josephine W.I. van Nierop ${ }^{a, b}$ Rebecca R. Snabel ${ }^{a}$ Margreet Langereis ${ }^{a, c}$ \\ Ronald J.E. Pennings ${ }^{a, b}$ Ronald J.C. Admiraala, ${ }^{a}$ Emmanuel A.M. Mylanus ${ }^{a, c}$ \\ Henricus P.M. Kunst ${ }^{a, b}$ \\ ${ }^{\mathrm{a}}$ Department of Otorhinolaryngology - Head and Neck Surgery, ${ }^{\mathrm{b}}$ Radboud Institute for Health Sciences, and \\ 'Donders Institute for Brain, Cognition and Behaviour, Radboud University Medical Center, \\ Nijmegen, The Netherlands
}

\section{Key Words}

Waardenburg syndrome . Speech perception .

Speech recognition - Language comprehension .

Additional disabilities - Inherited hearing impairment .

Genetic deafness

\section{Abstract \\ Objective: To analyse the benefit of cochlear implantation in young deaf children with Waardenburg syndrome (WS) compared to a reference group of young deaf children with- out additional disabilities. Method: A retrospective study was conducted on children with WS who underwent cochle- ar implantation at the age of 2 years or younger. The post- operative results for speech perception (phonetically bal- anced standard Dutch consonant-vocal-consonant word lists) and language comprehension (the Reynell Develop- mental Language Scales, RDLS), expressed as a language quotient (LQ), were compared between the WS group and the reference group by using multiple linear regression anal- ysis. Results: A total of 14 children were diagnosed with WS, and 6 of them had additional disabilities. The WS children were implanted at a mean age of 1.6 years and the 48 chil- dren of the reference group at a mean age of 1.3 years. The WS children had a mean phoneme score of $80 \%$ and a mean}

\section{KARGER}

E-Mail karger@karger.com www.karger.com/aud

\section{(c) 2016 The Author(s) \\ Published by S. Karger AG, Basel $1420-3030 / 16 / 0213-0187 \$ 39.50 / 0$}

This article is licensed under the Creative Commons AttributionNonCommercial-NoDerivatives 4.0 International License (CC BY NC-ND) (http://www.karger.com/Services/OpenAccessLicense) Usage and distribution for commercial purposes as well as any distribution of modified material requires written permission.
LQ of 0.74 at 3 years post-implantation, and these results were comparable to those of the reference group. Only the factor additional disabilities had a significant negative influence on auditory perception and language comprehension. Conclusions: Children with WS performed similarly to the reference group in the present study, and these outcomes are in line with the previous literature. Although good counselling about additional disabilities concomitant to the syndrome is relevant, cochlear implantation is a good rehabilitation method for children with WS.

(C) 2016 The Author(s)

Published by S. Karger AG, Basel

\section{Introduction}

A cochlear implant is an appropriate auditory rehabilitation option for patients with bilateral severe-to-profound sensorineural hearing impairment (SNHI). The post-operative performances of patients vary extensively; therefore, a thorough understanding of the factors underlying this variability is clinically relevant.

Waardenburg syndrome (WS) patients account for approximately $2-5 \%$ of the congenitally deaf population [Nayak and Isaacson, 2003; Tamayo et al., 2008] and usually express congenital non-progressive SNHI unilater- 
ally or bilaterally with a severe-to-profound character [Newton, 1990]. The hearing impairment expressed by WS has no typical audiogram shape, can be highly variable and can even be asymmetric [Pingault et al., 2010]. The syndrome, an auditory pigmentary syndrome, is caused by a disorder of the neural crest cells and is defined by the association of pigmentation anomalies of the hair, skin and irides as well as mild-to-profound congenital SNHI. The penetrance of WS is heterogeneous, resulting in variable phenotypes [Read and Newton, 1997].

Four types of WS have been described based on phenotypic characteristics (I-IV). These characteristics include the following: lateral displacement of the inner canthus (dystopia canthorum), partial depigmentation of the skin and hair (e.g. hypopigmented areas of the skin, white forelock, premature greying before the age of 30 years), and heterochromia of the irides or brilliant blue irides [Read and Newton, 1997; Waardenburg, 1951] (MIM No. 193500). In 1951, Waardenburg investigated patients of two different families with hearing impairment, the combination of features of which are now described as WS type I [Waardenburg, 1951]. Differentiation between type I and type II is made by the presence or absence of dystopia canthorum. Type III is additionally defined by upper limb abnormalities, and type IV is defined by the presence of Hirschsprung disease [Read and Newton, 1997]. WS type II and IV are both heterogeneous and are therefore subdivided (MIM No. 193510 and 277580). All types of WS are autosomal dominant disorders, except for a few subtypes of type II, caused by mutations in SNAI2, and type IV, caused by mutations in EDN3 (endothelin 3) or $E D N R B$ (endothelin receptor type B), in which the modes of transmission are also described to be autosomal recessive or 'not fully recessive - not fully dominant' [Pingault et al., 2010]. The genes involved in WS are PAX3 (WS type I and III), MITF (melanocyteassociated transcription factor) and SNAI2 (type II), SOX10 (type II and IV), and EDN3 and EDNRB (type IV) [Pingault et al., 2010; Read and Newton, 1997] (MIM No. 193500).

These genes play important roles in the neural crest in the differentiation and migration of melanocytes [Pingault et al., 2010; Read and Newton, 1997]. The pathways involve synergistic activation of PAX3 (a paired box 3 transcription factor) and SOX10 (encodes SRY-related HMG-box gene 10 transcription factor) on the proximal region of the MITF promoter [Bondurand et al., 2000; Potterf et al., 2000] (MIM No. 193500). MITF transactivates tyrosinases that are needed for melanogenesis and differentiation (MIM No. 193510). Both EDN3 and
$E D N R B$ play a role in the endothelin pathway and are responsible for Hirschsprung disease in patients with WS type IV [Read and Newton, 1997]. The EDNRB receptor is $G$ protein-coupled and ensures the development of neural crest-derived lineages by its signalling pathway [Pingault et al., 2010]. SNAI2 induces the epithelial-mesenchymal transition and is needed for the survival and migration of melanoblasts [Pingault et al., 2010] (MIM No. ${ }^{* 602150) \text {. }}$

The SNHI in patients with WS is considered to be the result of a thinned stria vascularis in the cochlea, caused by a lack of or a decreased number of melanocytes [Pingault et al., 2010; Read and Newton, 1997]. These cells produce endolymph which is necessary to build up a positive potential in the cochlea. This potential difference is needed for the excitation of the inner hair cells, which forward an electrical impulse to the otic nerves. The thin stria vascularis will ultimately lead to the collapse of Reissner's membrane followed by the destruction of the organ of Corti [Read and Newton, 1997; Steel and Barkway, 1989].

The aim of the present study was to describe the population of children with WS who underwent cochlear implantation at our department and to analyse the benefit of cochlear implantation in children with WS. Children implanted before the age of 2 years are likely to perform better than children implanted at an older age with respect to language skills [Boons et al., 2012; Manrique et al., 2004; Miyamoto et al., 2008]. As a consequence, paediatric implantation is currently performed as early as possible. The emphasis of this study was on this group of young children implanted at the age of 2 years or earlier. The long-term benefit on spoken speech perception and language development in young children with WS and a cochlear implant was analysed and compared to a reference group of children with cochlear implants without additional disabilities.

\section{Materials and Methods}

\section{Patients}

A retrospective study was conducted on children with WS who underwent cochlear implantation at the Department of Otorhinolaryngology of the Radboud University Medical Center, Nijmegen, The Netherlands. The inclusion of patients with WS was based on phenotype, because some WS genes still remain undiscovered [Pingault et al., 2010]. Therefore, the results of additional tests (computed tomography and vestibular function tests) and a clinical description of the children are presented. In some cases, WS was confirmed by mutation analysis. Genetic counselling was performed either before or after implantation. Age at implantation is 
an important factor for the outcome of a cochlear implant [Boons et al., 2012; Manrique et al., 2004; Miyamoto et al., 2008]. Accordingly, children with WS implanted at the age of 2 years or younger were selected and compared to a reference group as described below.

The educational settings were divided into three classes according to the Dutch educational system: mainstream education, special education for the deaf or hearing impaired, and special education for the deaf or hearing impaired with additional disabilities.

\section{Reference Group}

A group of 53 children earlier reported by Langereis and Vermeulen [2013] was used as a reference. The children underwent cochlear implantation before the age of 2 years at the Department of Otorhinolaryngology of the Radboud University Medical Center and attended mainstream education or the school for the deaf or hearing impaired. Children with additional disabilities were already excluded from this group; however, the group described by Langereis and Vermeulen [2013] included children with WS. The latter were also excluded from the reference group in the present study. After exclusion, the group consisted of 48 children.

\section{Speech Perception}

After cochlear implantation, speech perception was tested using standard phonetically balanced Dutch consonant-vocal-consonant (CVC) word lists. Loudspeakers were placed in a quiet room at a fixed distance of $1 \mathrm{~m}$ from the child. Words were administered at normal conversational level of $65 \mathrm{~dB}$ sound pressure level. Speech perception was expressed as a percentage of correct phonemes perceived.

\section{Language Comprehension}

Language development was evaluated with the Dutch translation of The Reynell Developmental Language Scales (RDLS) [Reynell, 1977; van Eldik et al., 1987]. This standardized test is extensively used to measure the comprehensive language development in young children between the ages of 1 year and 2 months and 6 years and 3 months. The RDLS consists of 87 items in 12 sections with gradually increasing difficulty. The test was administered by a speech therapist during the evaluation sessions after cochlear implantation.

Test results were expressed in different scores: standard score, percentile or age equivalent, based on the results of children with normal hearing. The obtained age equivalent was divided by the chronological age of the child, which resulted in the language quotient (LQ) [Boons et al., 2012]. By means of the LQ, a ratio was created between the performance of the child and the expected performance. An LQ of 1 represents an age-appropriate language level.

\section{Statistical Analysis}

Statistical analysis was performed using SPSS 20 (SPSS, Inc., Chicago, Ill., USA), and a p value $<0.05$ was considered statistically significant. The phoneme scores of the study and reference groups were compared and analysed with multiple linear regression (standard ENTER method). The LQs of these groups were analysed in a similar fashion. This method was used to correct for the confounding variables to obtain the isolated influence of WS on speech perception and language comprehension. The confounding variables were the following: age at implantation, type of implant, bilateral implantation and additional disabilities. The phoneme scores and LQs at the 36-month follow-up were used for analysis. If no phoneme score was indicated at 36 months, the next obtained score was used.

\section{Results}

\section{Children with WS}

\section{Patient Characteristics}

Fourteen children were diagnosed with WS and implanted at our department at the age of 2 years or younger. The group consisted of 8 males and 6 females. Of the 14 children, 10 received the CI24RE, 3 received the CI24M, and 1 child received the CI500, all from Cochlear. The mean age at first implantation was 1.61 years (SD 0.48 ). Two children underwent bilateral implantation before the time of the third-year evaluation of their first implant (table 1).

\section{Clinical Description}

The WS gene PAX3 was tested in 5 cases and MITF was tested in 9 cases. In 4 of the 14 cases the diagnosis was confirmed by mutation analysis. Patients 7,13 and 14 carried a mutation in the $M I T F$ gene (correlated with WS type II), and patient 11 carried a mutation in PAX3 (correlated with WS type I or III). Four children had dystopia canthorum. Five children had heterochromia of the irides, and another 2 children had bright blue eyes. A white forelock was present in 3 of the 14 children, and 1 child had white hair and eyebrows. Table 2 indicates with which type of WS the children were diagnosed. Six of the 14 children had additional disabilities (43\%). Two children (patients 3 and 14) had concomitant autism and delayed general or motor development. Patient 4 was affected by proprioceptive under-responsiveness that led to dyspraxia. Patient 6 had general and motor developmental delay. Patient 5 showed learning disabilities, and patient 9 had a developmental delay.

A pre-operative vestibular function test was performed in all WS children: 9 children showed normal results, 1 child showed areflexia (patient 5), 3 had hyporeflexia (patients 3, 7 and 14), and 1 had asymmetrical vestibular function with right hyperreflexia (patient 6). Pre-operative computed tomography was performed in all 14 children. Three children (patients 7, 13 and 14) had opacification of the middle ear and mastoid that was suspicious for the presence of otitis media. Patient 4 had a mildly enlarged vestibulum, and patients 8,10 and 12 had an enlarged vestibular aqueduct: 1 showed an incomplete par- 
Table 1. Characteristics of all children with WS and the reference group

\begin{tabular}{lcc}
\hline & $\begin{array}{l}\text { WS } \\
(\mathrm{n}=14)\end{array}$ & $\begin{array}{l}\text { Reference group } \\
(\mathrm{n}=48)\end{array}$ \\
\hline $\begin{array}{l}\text { Gender, } \mathrm{n}(\%) \\
\text { Female }\end{array}$ & $6(42.86)$ & $24(50)$ \\
Male & $8(57.14)$ & $24(50)$ \\
Age at implantation (SD), years & $1.61(0.48)$ & $4.32(0.33)$ \\
Bilateral, $\mathrm{n}(\%)$ & $2(14.28)$ & $20(41.67)$ \\
Type of implant, $\mathrm{n}(\%)$ & $10(71.43)$ & $7(14.58)$ \\
CI24RE & $3(21.43)$ & \\
CI24M & $1(7.14)$ & $86(10)$ \\
CI500 & $80(23)$ & \\
Phoneme score (SD) & $91(6)$ & $0.87(0.15)$ \\
36 months ( $=14)$ & $0.74(0.21)$ & \\
36 months without additional problems $(\mathrm{n}=8)$ & $0.87(0.19)$ & \\
RDLS LQ (SD) & & \\
36 months (n=14) & & \\
36 months without additional problems $(\mathrm{n}=7)$ & & \\
\hline The age at implantation refers to the age at the first implantation. & \\
\hline
\end{tabular}

Table 2. Individual characteristics and post-operative test results of the children with WS

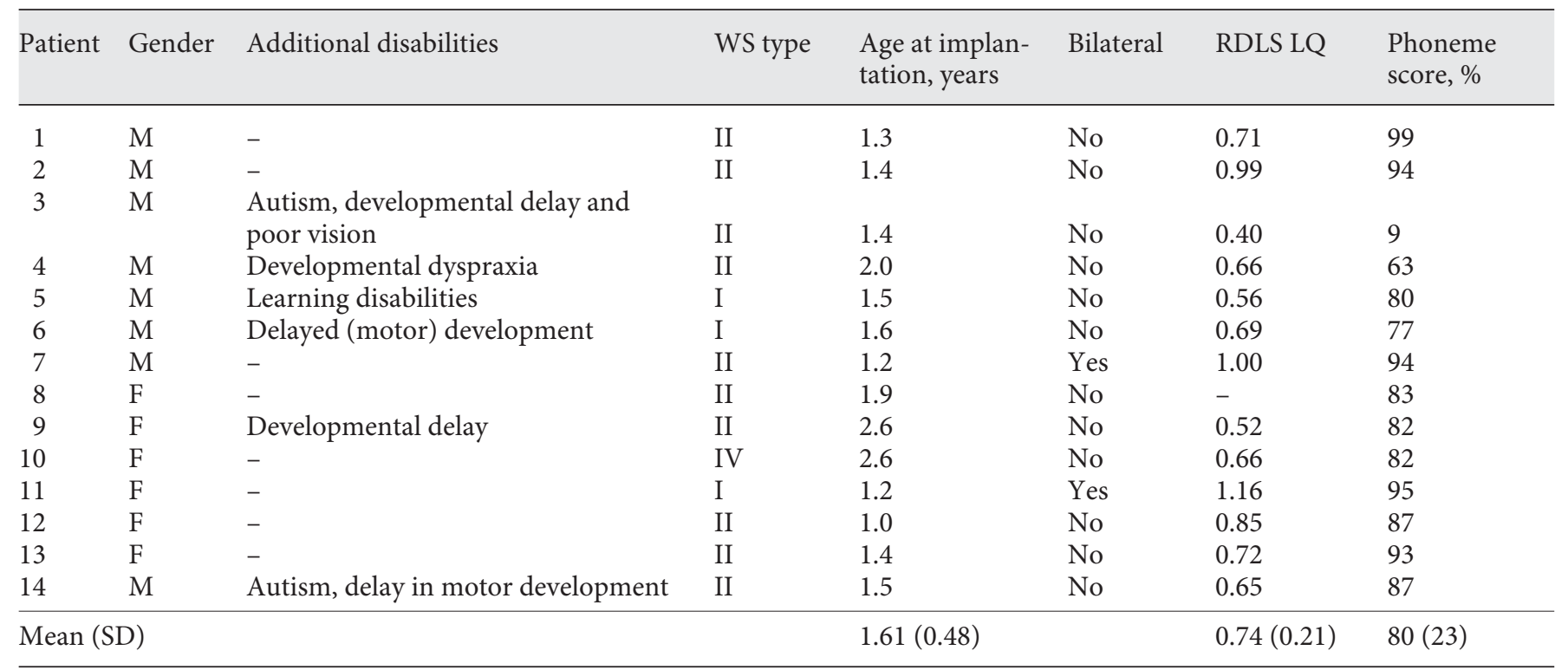

WS type: contains the type of WS that corresponds to the combination of phenotypic features reported for the patient.

titioning of the cochlea type II (patient 8) and another child had a hypoplastic superior semicircular canal (patient 12). No other inner ear abnormalities were found. Patient 6 presented with a bifrontotemporal reduction of the brain without a known cause.
Most of the children $(n=9)$ were attending a school for the deaf or hearing impaired at the 3-year follow-up. Two children (patients 3 and 6) attended special educational settings for the deaf or hearing impaired with additional disabilities. The other 3 children (patients 1, 2 
Table 3. Individual RDLS LQ and phoneme scores of the children with WS at different follow-up times: 1-3 years of RDLS scores and 3-6 years or more of phoneme scores

\begin{tabular}{|c|c|c|c|c|c|c|c|c|c|}
\hline Patient & Bilateral & $\begin{array}{l}\text { RDLS LQ } \\
\text { score } 1 \text { year }\end{array}$ & $\begin{array}{l}\text { RDLS LQ } \\
\text { score } 2 \text { years }\end{array}$ & $\begin{array}{l}\text { RDLS LQ } \\
\text { score } 3 \text { years }\end{array}$ & $\begin{array}{l}\text { Phoneme score } \\
3 \text { years, \% }\end{array}$ & $\begin{array}{l}\text { Phoneme score } \\
4 \text { years, \% }\end{array}$ & $\begin{array}{l}\text { Phoneme score } \\
5 \text { years, \% }\end{array}$ & $\begin{array}{l}\text { Phoneme score } \\
\geq 6 \text { years, } \%\end{array}$ & $\begin{array}{l}\text { Follow-up, } \\
\text { years }\end{array}$ \\
\hline 1 & No & 0.51 & 0.59 & 0.71 & 99 & 93 & 90 & 90 & 8.0 \\
\hline 3 & No & - & - & 0.40 & 9 & 9 & 9 & 9 & 6.7 \\
\hline 4 & No & 0.59 & 0.56 & 0.66 & 63 & - & - & 87 & 10.7 \\
\hline 5 & No & 0.43 & 0.54 & 0.56 & - & 80 & 94 & 84 & 12.1 \\
\hline 8 & No & 0.38 & 0.44 & - & 83 & - & - & - & 3.2 \\
\hline 9 & No & 0.36 & 0.53 & 0.52 & 82 & 78 & 75 & 81 & 7.1 \\
\hline 10 & No & 0.57 & 0.67 & 0.66 & - & 82 & - & 88 & 14.5 \\
\hline 11 & Yes & 0.92 & 1.04 & 1.16 & 95 & 95 & - & 100 & 7.2 \\
\hline 12 & No & 0.67 & 0.81 & 0.85 & 87 & 96 & 100 & - & 6.1 \\
\hline
\end{tabular}

Follow-up: this column describes the period in years after implantation until the time of analysis.

and 10) were attending mainstream education at the 3-year follow-up and had no additional disabilities. In time, 2 of the children (patients 11 and 13) who first attended special education for the deaf or hearing impaired switched to a mainstream educational setting. These 2 children had no additional disabilities.

\section{Reference Group}

Patient Characteristics

A group of 48 children implanted before the age of 2 years at our department was used as a reference group; $50 \%$ of the children were male. Of the 48 children, 21 received the CI24M implant, 20 received the CI24RE, and 7 received the CI500, all from Cochlear. The mean age at first implantation was 1.32 years (SD 0.33). Four children received their second implant sequentially, before the time of the third-year evaluation of their first implant (table 1).

\section{Speech Perception}

The mean phoneme scores found in the analysis were $80 \%$ (SD 23) and $86 \%$ (SD 10) for the study and reference groups, respectively. The missing data of the 8 children from the reference group were acknowledged as randomly missing. Table 3 indicates the individual scores at the different follow-up times of the children with WS. Figure la shows the mean results of speech perception at the dif- ferent follow-up times for the study and reference groups. The mean phoneme scores of the children with WS were slightly below those of the reference group and remained approximately the same during the consecutive follow-up (fig. 1a). The 8 WS children without additional disabilities had a mean phoneme score of 91\% (SD 6).

Multiple linear regression analysis showed a non-significant difference in phoneme score of 2\% (SE 5, p = 0.66 ) between the children with WS and the reference group. The factor additional disabilities had a significant negative influence on the phoneme score, resulting in a difference of $25 \%$ (SE 7; $\mathrm{p}=0.001$ ).

\section{Language Comprehension}

The language comprehension of the children with WS was compared to the reference group (fig. 1b). All children of the reference group had results for the RDLS at the time of the third-year evaluation. In the study group, 1 result for the RDLS was missing, and 1 of the 14 children did not yet have a third-year evaluation at the time of analysis. The mean LQ for language comprehension was 0.74 (SD 0.21) for the children with WS and 0.87 (SD 0.15 ) for the reference group. The 7 WS children without additional problems had a mean LQ of 0.87 (SD 0.19).

With the regression analysis, a non-significant difference was found between the study group and the reference group. The difference in LQ between the groups was 

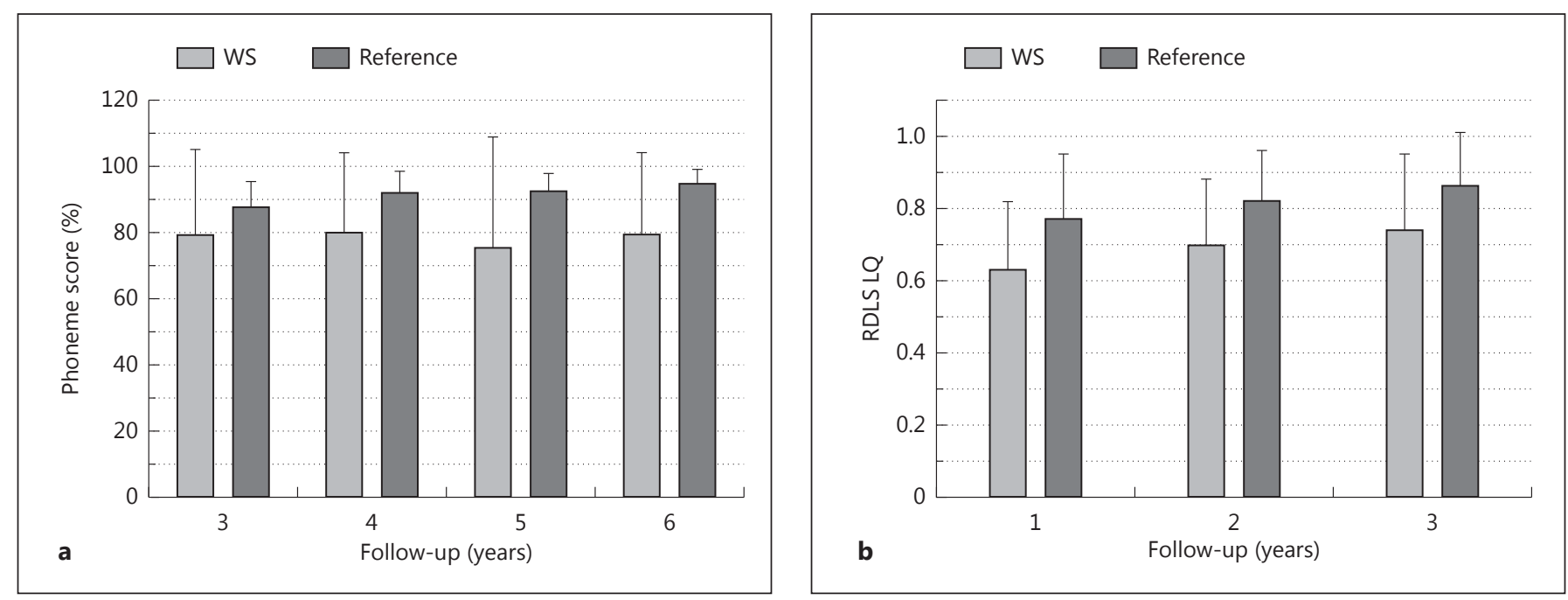

Fig. 1. Post-implantation performance. a Performance of speech perception. The mean and SD of the correct phoneme scores for the children with WS and the reference group at 3-6 years or more of follow-up. The phoneme scores were measured on a conversational stimulus level of $65 \mathrm{~dB}$. b Performance of language comprehension. The mean and SD of the RDLS expressed in LQ for the children with WS and the reference group at 1-3 years of follow-up.

0.023 (SE 0.069; $\mathrm{p}=0.74$ ). We adjusted for the confounding factors (age at implantation, type of implant, bilateral implantation and additional disabilities). Only the factor additional disabilities had a significant negative influence on the language comprehension ratio with 0.25 (SE 0.089; $\mathrm{p}=0.008)$.

\section{Discussion}

The aim of this study was to assess the long-term benefit of cochlear implantation on speech perception and language comprehension in a cohort of young children with WS. The children with WS performed comparable to a selected reference group on speech perception and comprehensive language development during 3 years of follow-up. Based on these results, cochlear implantation is a good rehabilitation option for children with WS. Most WS children without additional disabilities had an excellent phoneme score, with a mean of $91 \%$ (SD 6.13). According to earlier reports, a phoneme score of approximately $85 \%$ allows children to acquire an age-appropriate language level [Langereis et al., 2011], which is confirmed in our cohort. The WS children without additional disabilities had a mean LQ of 0.87 (SD 0.19), which is within 1 deviation of scores in normally developed children with normal hearing (1 SD below the norm is 0.82 ) [Boons et al., 2012].
Various other studies have described the outcome of cochlear implantation in patients with WS (table 4), presenting overall good results with respect to speech perception and speech intelligibility. Rajput et al. [2003], however, reported significantly lower receptive language and speech intelligibility scores for children with syndromic aetiologies (including 5 with WS) in comparison to children with non-syndromic aetiologies [Rajput et al., 2003]. In the latter study, no differentiation was made between syndromic aetiologies, and therefore the outcome of the children with WS alone was not mentioned. This explains how these results could differ from those of the present study.

Approximately one third of the hearing-impaired population with a cochlear implant has additional disabilities [Birman et al., 2012]. The population of children with cochlear implants and additional disabilities has achieved significantly lower outcomes in both auditory perception and language development; nonetheless, a variability has been described [Baldassari et al., 2009; Birman et al., 2012; Edwards et al., 2006; Holt and Kirk, 2005; Meinzen-Derr et al., 2010; Waltzman et al., 2000]. However, some authors mention a benefit of cochlear implantation in patients with disabilities [Birman et al., 2012; Edwards et al., 2006; Holt and Kirk, 2005; Waltzman et al., 2000]. Additional disabilities are more frequently associated with syndromic aetiologies, for instance WS [Birman et al., 2012; Rajput et al., 2003]. 
Table 4. Previous literature concerning implanted patients with WS

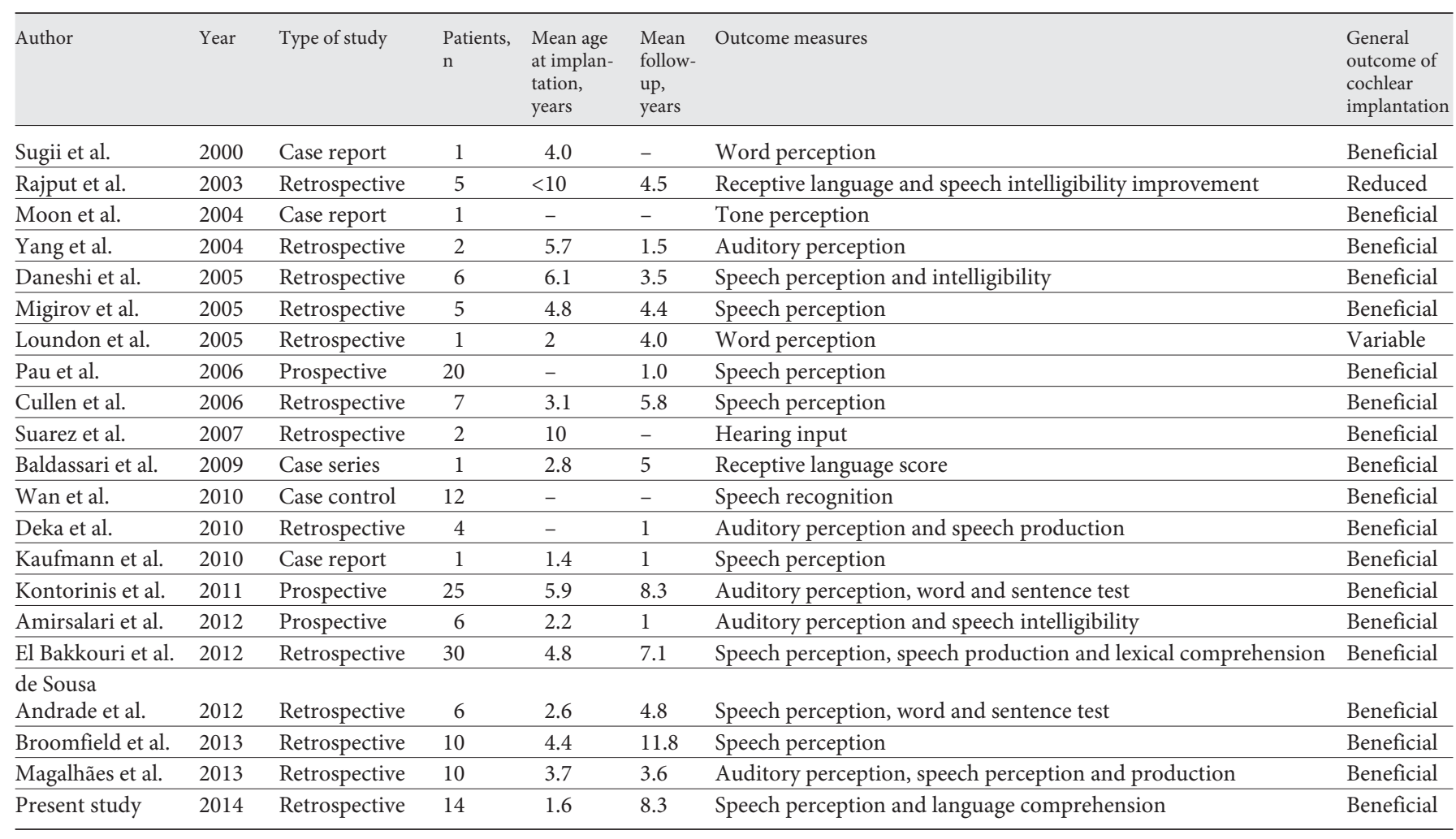

One report described the outcome for WS with the association of behavioural disorders (acceptance of device and co-operation with pedagogues), which would cause temporary difficulties for rehabilitation [Kontorinis et al., 2011]. However, the report indicates cochlear implantation as a good rehabilitation method, because the rehabilitation problems did not have any significant consequences. The analysis of the present study showed a significant negative influence of the additional disabilities on phoneme scores and language comprehension LQ at 3 years post-implantation. This underlines the importance of thorough testing for additional disabilities, to make the counselling of parents as accurate as possible. Preoperative counselling, therefore, should include realistic information about the influence of additional disabilities on the benefits of cochlear implant in children with WS.

In summary, cochlear implantation appears to be a good rehabilitative option for patients with WS. Because additional disabilities cause variable and unpredictable outcomes, it is necessary to remain cautious. Of course, this is always important for children with hearing impairment and comorbidities and is independent from the aetiology.

Cochlear Implantation and Waardenburg Syndrome
With early diagnosis of severe-to-profound hearing impairment, paediatric implantation could be performed earlier, which would lead to even better performances [Boons et al., 2012; Manrique et al., 2004; Miyamoto et al., 2008]. Nevertheless, more research is needed into the different genotypes that cause WS. More knowledge about the disease genes that cause WS would improve early counselling of parents.

\section{Conclusion}

This study shows comparable performances in longterm speech perception and language comprehension between young implanted children with and without WS. This result indicates that cochlear implantation is a good rehabilitation method for patients with WS.

\section{Disclosure Statement}

Cochlear Benelux provided financial support for this study. There are no potential conflicts of interest for the individual authors in relation to the content of this article. 


\section{References}

- Amirsalari S, Ajallouyean M, Saburi A, Haddadi Fard A, Abed M, Ghazavi Y: Cochlear implantation outcomes in children with Waardenburg syndrome. Eur Arch Otorhinolaryngol 2012;269:2179-2183.

- Baldassari CM, Schmidt C, Schubert CM, Srinivasan P, Dodson KM, Sismanis A: Receptive language outcomes in children after cochlear implantation. Otolaryngol Head Neck Surg 2009;140:114-119.

Birman CS, Elliott EJ, Gibson WP: Pediatric cochlear implants: additional disabilities prevalence, risk factors, and effect on language outcomes. Otol Neurotol 2012;33:1347-1352.

Bondurand N, Pingault V, Goerich DE, Lemort N, Sock E, Le Caignec C, Wegner M, Goossens M: Interaction among SOX10, PAX3 and $M I T F$, three genes altered in Waardenburg syndrome. Hum Mol Genet 2000;9:19071917.

Boons T, Brokx JP, Dhooge I, Frijns JH, Peeraer L, Vermeulen A, Wouters J, van Wieringen A: Predictors of spoken language development following pediatric cochlear implantation. Ear Hear 2012;33:617-639.

Broomfield SJ, Bruce IA, Henderson L, Ramsden RT, Green KM: Cochlear implantation in children with syndromic deafness. Int J Pediatr Otorhinolaryngol 2013;77:1312-1316.

-Cullen RD, Zdanski C, Roush P, Brown C, Teagle $\mathrm{H}$, Pillsbury HC 3rd, Buchman C: Cochlear implants in Waardenburg syndrome. Laryngoscope 2006;116:1273-1275.

Daneshi A, Hassanzadeh S, Farhadi M: Cochlear implantation in children with Waardenburg syndrome. J Laryngol Otol 2005;119:719723.

Deka RC, Sikka K, Chaturvedy G, Singh CA, Venkat Karthikeyan C, Kumar R, Agarwal S: Cochlear implantation in Waardenburg syndrome: the Indian scenario. Acta Otolaryngol 2010;130:1097-1100

de Sousa Andrade SM, Monteiro AR, Martins JH, Alves MC, Santos Silva LF, Quadros JM, Ribeiro CA: Cochlear implant rehabilitation outcomes in Waardenburg syndrome children. Int J Pediatr Otorhinolaryngol 2012;76: 1375-1378.

Edwards LC, Frost R, Witham F: Developmental delay and outcomes in paediatric cochlear implantation: implications for candidacy. Int J Pediatr Otorhinolaryngol 2006;70:1593 1600.

-El Bakkouri W, Loundon N, Thierry B, Nevoux J, Marlin S, Rouillon I, Garabedian EN: Cochlear implantation and congenital deafness: perceptive and lexical results in 2 genetically pediatric identified populations. Otol Neurotol 2012;33:539-544

Holt RF, Kirk KI: Speech and language development in cognitively delayed children with cochlear implants. Ear Hear 2005;26:132-148.
Kaufmann L, Sauter TB, Lee DJ: Dysplasia of the cerebellum in Waardenburg syndrome: outcomes following cochlear implantation. Int J Pediatr Otorhinolaryngol 2010;74:93-96.

Kontorinis G, Lenarz T, Giourgas A, Durisin M, Lesinski-Schiedat A: Outcomes and special considerations of cochlear implantation in Waardenburg syndrome. Otol Neurotol 2011;32:951-955.

Langereis M, Vermeulen A: Duidelijke meerwaarde van cochleaire implantatie. Logopedie 2013;9:16-24.

Langereis M, Vermeulen A, Snik AFM, Mylanus EAM: E028 long term educational and psychosocial outcomes. Int J Pediatr Otorhinolaryngol 2011;75:66.

Loundon N, Rouillon I, Munier N, Marlin S, Roger G, Garabedian EN: Cochlear implantation in children with internal ear malformations. Otol Neurotol 2005;26:668-673.

Magalhães AT, Samuel PA, Goffi-Gomez MVS, Tsuji RK, Brito R, Bento RF: Audiological outcomes of cochlear implantation in Waardenburg syndrome. Int Arch Otorhinolaryngol 2013;17:285-290.

Manrique M, Cervera-Paz FJ, Huarte A, Molina $\mathrm{M}$ : Advantages of cochlear implantation in prelingual deaf children before 2 years of age when compared with later implantation. Laryngoscope 2004;114:1462-1469.

Meinzen-Derr J, Wiley S, Grether S, Choo DI: Language performance in children with cochlear implants and additional disabilities. Laryngoscope 2010;120:405-413.

Migirov L, Henkin Y, Hildesheimer M, Muchnik C, Kronenberg J: Cochlear implantation in Waardenburg's syndrome. Acta Otolaryngol 2005; 125:713-717.

Miyamoto RT, Hay-McCutcheon MJ, Kirk KI, Houston DM, Bergeson-Dana T: Language skills of profoundly deaf children who received cochlear implants under 12 months of age: a preliminary study. Acta Otolaryngol 2008;128:373-377.

Moon SK, Choi HS, Lee SJ, Choung YH, Park K: Cochlear implantation in a case with Waardenburg syndrome. Cochlear Implants Int 2004;5(suppl 1):212-214.

Nayak CS, Isaacson G: Worldwide distribution of Waardenburg syndrome. Ann Otol Rhinol Laryngol 2003;112:817-820.

Newton V: Hearing loss and Waardenburg's syndrome: implications for genetic counselling. J Laryngol Otol 1990;104:97-103.

Pau H, Gibson WP, Gardner-Berry K, Sanli H: Cochlear implantations in children with Waardenburg syndrome: an electrophysiological and psychophysical review. Cochlear Implants Int 2006;7:202-206.
Pingault V, Ente D, Dastot-Le Moal F, Goossens M, Marlin S, Bondurand N: Review and update of mutations causing Waardenburg syndrome. Hum Mutat 2010;31:391-406.

Potterf SB, Furumura M, Dunn KJ, Arnheiter H, Pavan WJ: Transcription factor hierarchy in Waardenburg syndrome: regulation of MITF expression by SOX10 and PAX3. Hum Genet 2000;107:1-6.

Rajput K, Brown T, Bamiou DE: Aetiology of hearing loss and other related factors versus language outcome after cochlear implantation in children. Int J Pediatr Otorhinolaryngol 2003;67:497-504

Read AP, Newton VE: Waardenburg syndrome. J Med Genet 1997;34:656-665.

Reynell JK: Manual for the Reynell Developmental Language Scales (revised). Windsor, NFER Publishing, 1977.

- Steel KP, Barkway C: Another role for melanocytes: their importance for normal stria vascularis development in the mammalian inner ear. Development 1989;107:453-463.

Suarez H, Angeli S, Suarez A, Rosales B, Carrera $\mathrm{X}$, Alonso R: Balance sensory organization in children with profound hearing loss and cochlear implants. Int J Pediatr Otorhinolaryngol 2007;71:629-637.

Sugii A, Iwaki T, Doi K, Takahashi Y, Yamamoto K, Fuse Y, Kobayashi R, Kubo T: Cochlear implant in a young child with Waardenburg syndrome. Adv Otorhinolaryngol 2000;57:215219.

Tamayo ML, Gelvez N, Rodriguez M, Florez S, Varon C, Medina D, Bernal JE: Screening program for Waardenburg syndrome in Colombia: clinical definition and phenotypic variability. Am J Med Genet A 2008;146A:10261031.

van Eldik MCM, Schlichting JEPT, Lutje Spelberg HJ, van der Meulen BF, van der Meulen SJ: Reynell Test for Comprehensive Language. Nijmegen, Berkhout Nijmegen, 1987.

$\checkmark$ Waardenburg PJ: A new syndrome combining developmental anomalies of the eyelids, eyebrows and nose root with pigmentary defects of the iris and head hair and with congenital deafness. Am J Hum Genet 1951;3:195-253.

Waltzman SB, Scalchunes V, Cohen NL: Performance of multiply handicapped children using cochlear implants. Am J Otol 2000;21: 329-335.

Wan L, Guo M, Chen S, Liu S, Chen H, Gong J: Cochlear implantation in patients with Waardenburg syndrome type II (in Chinese). Lin Chung Er Bi Yan Hou Tou Jing Wai Ke Za Zhi 2010;24:436-438.

Yang HM, Lin CY, Chen YJ, Wu JL: The auditory performance in children using cochlear implants: effects of mental function. Int J Pediatr Otorhinolaryngol 2004;68:1185-1188. 